\title{
THE SWAPPING APPROACH IN THE COURSE OF LAND CONSOLIDATION: CASE STUDY OF UKRAINE
}

\author{
Mykola MALASHEVSKYI ${ }^{*}$, Olena MALASHEVSKA ${ }^{2} 2$ \\ ${ }^{1}$ Problems of Land Development and Land Cadastre Department, The Institute of Land Management \\ of National Academy of Agrarian Sciences of Ukraine, Kyiv, Ukraine \\ ${ }^{2}$ Geodesy and Cartography Department, National University of Life and Environmental Sciences of Ukraine, \\ Kyiv, Ukraine
}

Received 20 July 2020; accepted 29 October 2021

\begin{abstract}
The paper is concerned with the issues of the voluntary land consolidation using the exchange method at land relations reforming. The objective of the article is the substantiation of the exchange method aiming at the large and small land owners (land users) land tenure optimization and the formation of approaches with the help of which the mutual alignment of their interests can be achieved. Land plot ownership and tenure rights exchange by the relative value has been substantiated. It is suggested to define the relative value based on the principle of juxtaposition of land plots by their qualitative, spatial and technological characteristics. The land plots exchange modelling has been improved according to the relative value application and due to the existing land plots boundaries retaining at the exchange. The effectiveness of the suggested land plots exchange method has been demonstrated at the land tenure optimization of an agricultural enterprise and some households in Kyiv Region. Alternative land consolidation projects based on the land plots exchange have been developed, the results of which demonstrate the advantages of the voluntary land consolidation based on the suggested methodology.
\end{abstract}

Keywords: land consolidation, land reallotment, land mass, land exchange, relative value, agricultural land.

\section{Introduction}

The importance of land consolidation for the rural areas sustainable development is currently acknowledged worldwide (Giovarelli \& Bledsoe, 2001; Vitikainen, 2004; Hartvigsen, 2014; Food and Agriculture Organization of the United Nations [FAO], 2003). The search of the most effective mechanisms of its implementation is an urgent issue. In this context, the issue of the alignment to the conditions and objectives of land consolidation is singled out (FAO, 2012, 2003). It is substantiated by the diversity of land consolidation approaches and mechanisms of their implementation (Vitikainen, 2004; Thomas, 2006; Hartvigsen, 2016).

At land consolidation, land plots exchange is recognized to be one of key tools (Sonnenberg, 2002), ownership rights exchange is recognized to be the key principle (Louwsma et al., 2014). The effectiveness of the swapping approach is proven as a constituent of land consolidation (Yimer, 2014). Land exchange is the most elaborately treated at the voluntary land consolidation and individual land owners initiatives (Gedefaw et al., 2019; Sulonena et al., 2017; Bavarian Ministry of Agriculture and Forestry, 2006).

The article concentrates on the issues of the effective exchange method implementation at land consolidation in the context of land relations development. In Ukraine, an attempt at the regulation of the issues of land exchange of all forms of property within the agricultural land masses was made as the first stage of the land consolidation legislation development (Verkhovna Rada of Ukraine, 1998, 2001). However, there is no technical support of such initiatives, recommended by Voluntary Guidelines on the Responsible Governance of Tenure of Land, Fisheries and Forests in the Context of National Food Security (FAO, 2012).

Currently, significant power has been accredited to the local authorities; land users motivation concerning the optimal land tenure through land consolidation is increased due to the land market establishment. Ukrainian legislation favours land users using more than $75 \%$ of land plots of an agricultural land mass concerning land

*Corresponding author. E-mail: mykola.malashevskyi@gmail.com 
consolidation issues (Verkhovna Rada of Ukraine, 1998, 2001). Such land user is considered to be an individual (company, or other entity) enjoying the usage right of the predominant agricultural land mass share (hereafter referred to as a large land user). According to the existing social and economic conditions, there is a request for the development of a so called user manual reflecting the clear and transparent land plots reallotment criteria.

The objective of the article is the substantiation of the exchange method aiming at the large and small land owners (land users) land tenure optimization and the formation of approaches with the help of which the mutual alignment of their interests can be achieved.

\section{Materials and methods}

Normative monetary value is defined as the key agricultural land exchange tool in Ukraine. Arable land plot normative monetary value is calculated by the formula (Cabinet of Ministers of Ukraine, 2006):

$$
V=\frac{N_{r}}{B g_{r}} \sum_{i=1}^{n} S_{i} B g_{i},
$$

where $V$ - is the land plot normative monetary value; $N_{r}$ is the capitalized rental income norm (uniform for a region), UAH/ha; $B g_{r}$ - is the soil fertility ball by a 100 -ball scale (ball-bonitet), average for the region; $B g_{i}$ - is the soil ball-bonitet of the soil suitability group; $S_{i}-$ is the soil suitability group area of the $i$-th soil of the land plot; $n$ is the number of soil suitability groups of the land plot.

According to the legislation of Ukraine (Verkhovna Rada of Ukraine, 1998, 2001), land plots exchange should be carried out by the following rules:

- Land plots to be exchanged should be placed within the same land mass;

- Land exchange is carried out for the striped land plots, provided their placement impedes the rational land use;

- Normative monetary value of the exchanged land plots should vary by no more than $10 \%$.

The set exchange conditions do not guarantee the effective land plots reallocation for several reasons. First of all, the majority of land masses consists of land plots with almost the same normative monetary value (within $10 \%$ ), excluding some land plots, formed by the division at inheritance. However, such land plots significantly differ in terms of configuration and placement.

Close normative monetary value of land plots within a land mass is predefined by the peculiarities of the distribution of the state and collective agricultural enterprises property and privatisation of land plots by private persons. According to the conditions, secured by legislation, there is a great number of land plots exchange options and in order to choose the optimal one the development of an additional methodology is needed. The abovementioned facts pose a threat (FAO, 2017) in terms of the involvement in the exchange through a court proceeding without the consent of the land owner.
On the other hand, as we can see from formula (1), the arable land plots normative monetary value within a region varies depending on ball-bonitet exclusively as the soil fertility characteristics. At calculating the normative monetary value according to the existing methodology, important for agricultural activity land plots characteristics are not considered, particularly, configuration, relief, ground water depth level, need for irrigation, placement of household buildings and target markets, etc. If a land tenure includes a number of land plots, it is reasonable to consider their mutual placement.

Respectively, it is recommended to apply relative value to substantiate the exchange (FAO, 2003), which is suggested to be defined by spatial, technological and qualitative characteristics. Land reallotment modelling approaches based on the minimization of distances between land plots of a certain land owner or user have been introduced (Kik, 1980; Mihajlovic et al., 2011). It is suggested to improve the optimization model based on the peer exchange by qualitative and spatial and technological conditions (Bugaienko, 2019) taking into consideration land exchange with retaining the existing land plots boundaries.

Land plots exchange with retaining the existing land plots boundaries has a set of advantages connected with the simplification of the transactions approval and legal description. It is worth mentioning, at the optimization of the rented land tenure the exchange is carried out by land sublease agreement. In such cases, land sublease agreement provisions are restricted by the land lease agreement terms and conditions, in particular, in terms of area and placement.

We scrutinize $k$ land plots, the placement of which poses inconvenience for the economic activity, and $j$ land plots, suitable for exchange. Herewith, $k \leq j$. Key reallotment precondition is exchange by relative value which can vary for the land plots to be exchanged within the range of $10 \%$. Considering the abovementioned, it is suggested to adhere to the condition:

$$
0.9 \leq \frac{K_{j i} B_{j i} S_{j i}}{K_{k i} B_{k i} S_{k i}} \leq 1.1, \quad i=1,2, \ldots, n,
$$

where $S_{j}, S_{k}$ - are the areas of the exchanged land plots; $B_{j}, B_{k}$ - is the average ball-bonitet of the exchanged land plots; $K_{j}, K_{k}$ - is the spatial and technological characteristics coefficient of the exchanged land plots; $n$ - is the number of the executed exchanges.

Striped land plots, land plots with a placement causing the development of point row areas at cultivating, broken boundaries causing the impaired transport accessibility, tillage, impaired plowing and crop cultivation technology violations, etc. are involved into the process of exchange. Peer land plots are chosen among land plots situated at the land mass boundary.

The exchange has been executed in an agricultural enterprise situated in Kyiv Region, formed from rented privately owned land plots and include eleven land masses (Figure 1). 
There are preconditions for the spatial optimization due to the peculiarities of land plots placement, which are not favourable for the agricultural enterprise economic activities and private land owners and users (Figures 2-9).

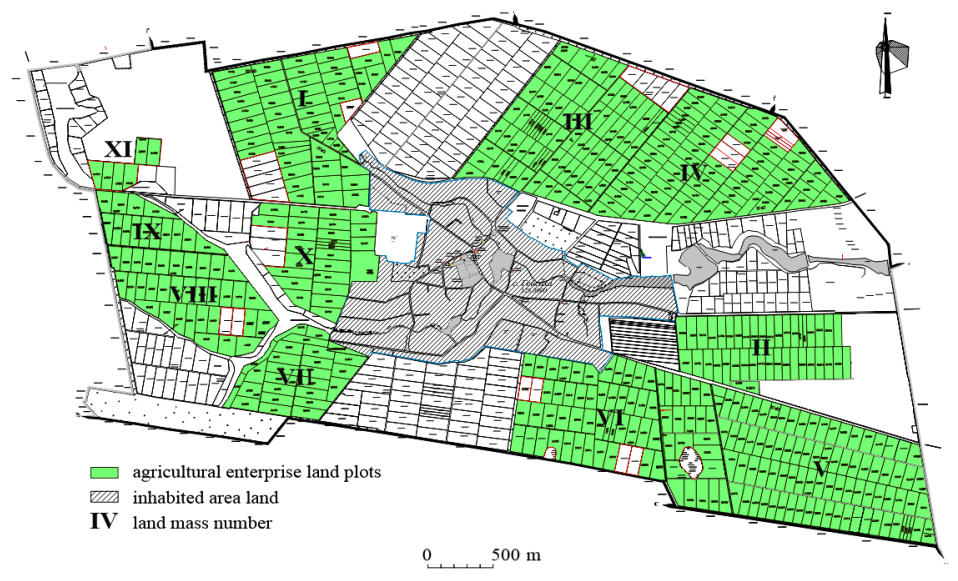

Figure 1. Agricultural enterprise land tenure
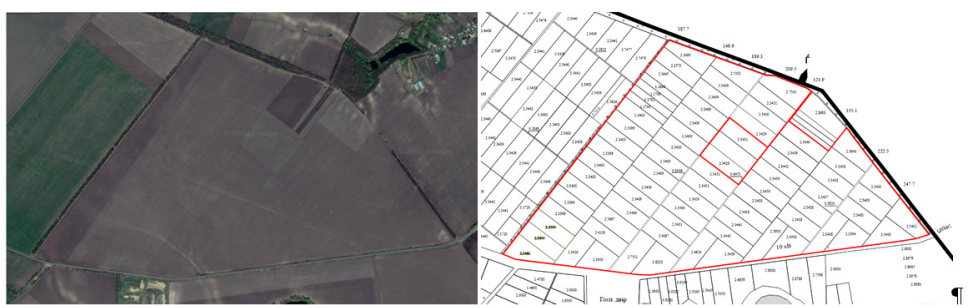

Figure 2. Land plots placement and usage within the fourth land mass (source: https://map.land.gov.ua/)
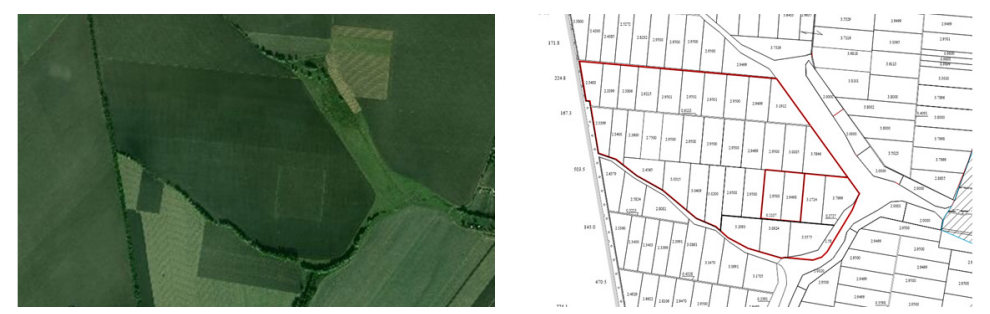

Figure 3. Land plots placement and usage within the eighth land mass (source: https://map.land.gov.ua/)
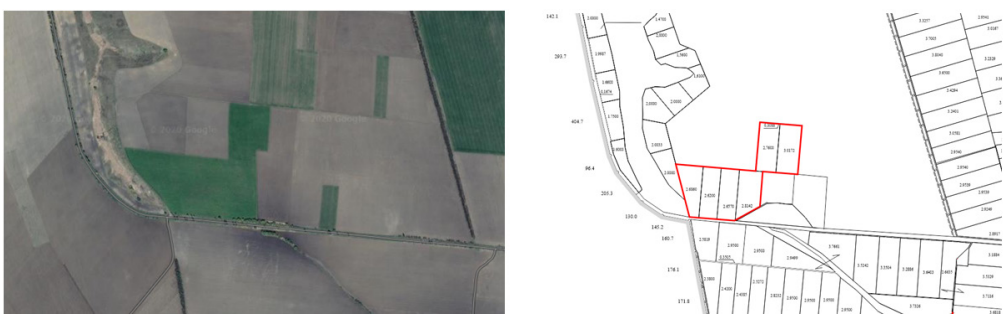

Figure 4. Land plots placement and usage within the eleventh land mass (source: https://map.land.gov.ua/)

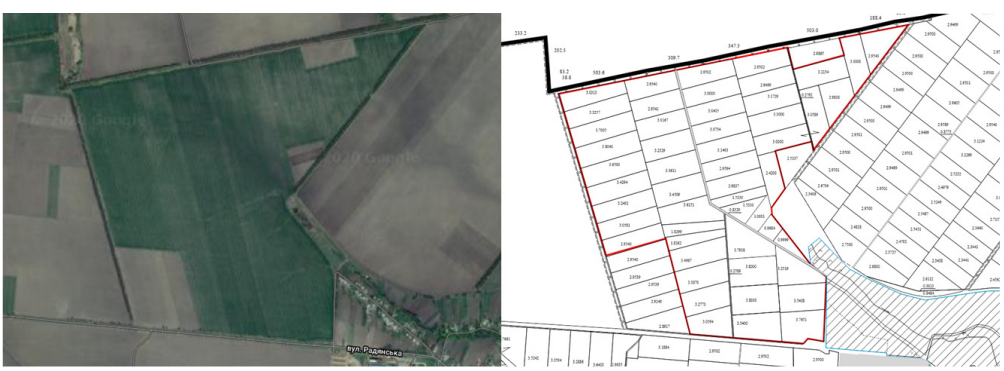

Figure 5. Land plots placement and usage within the first land mass (source: https://map.land.gov.ua/) 


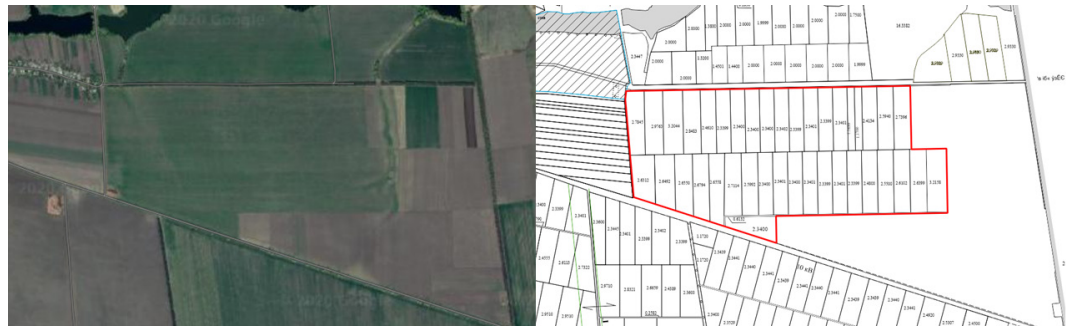

Figure 6. Land plots placement and usage within the second land mass (source: https://map.land.gov.ua/)

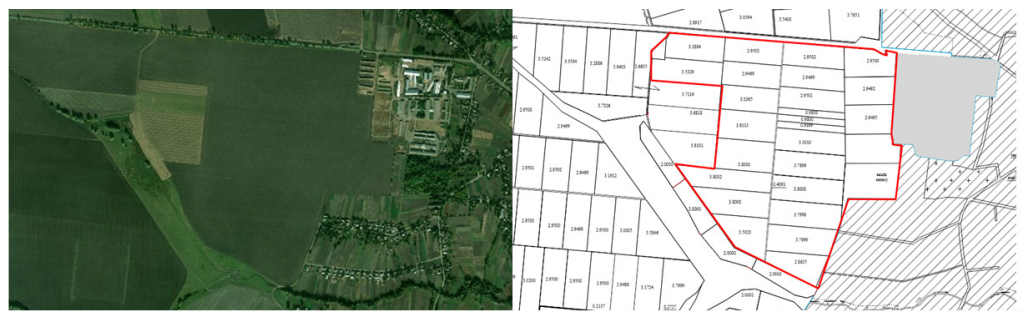

Figure 7. Land plots placement and usage within the third land mass (source: https://map.land.gov.ua/)
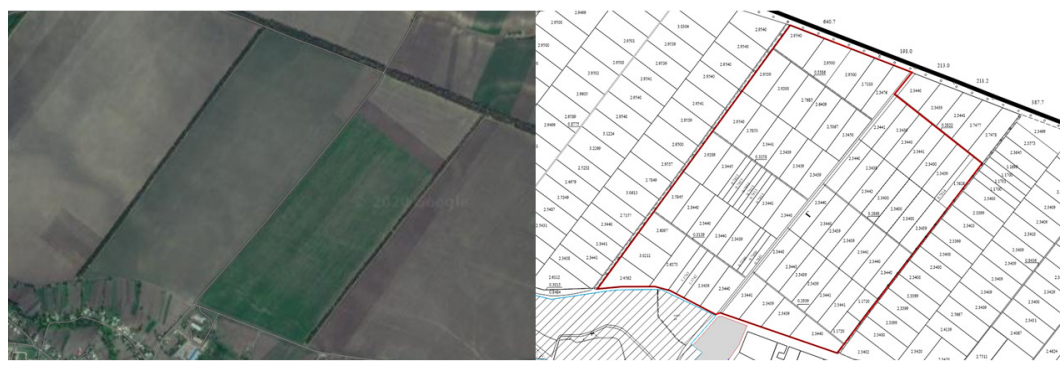

Figure 8. Land plots placement and usage within the tenth land mass (source: https://map.land.gov.ua/)

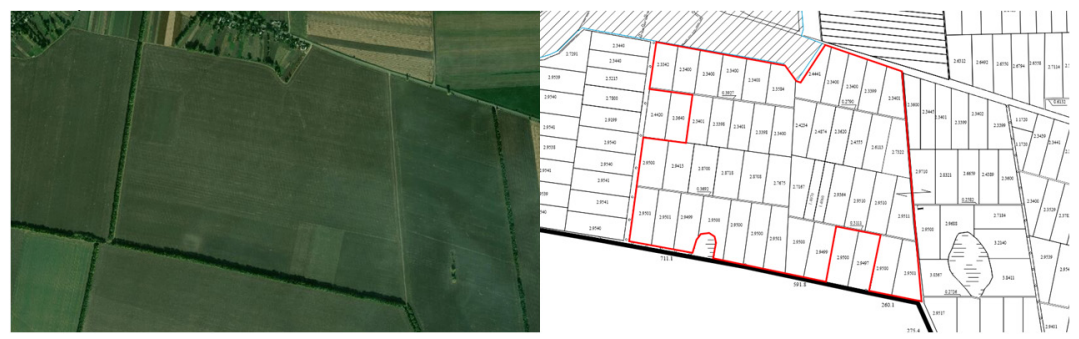

Figure 9. Land plots placement and usage within the sixth land mass (source: https://map.land.gov.ua/)

Land tenures have complicated technological conditions due to their placement towards natural and artificial boundaries like roads, tree belts, water-logged areas (the sixth, seventh and eighth land mass) and due to the use of land plots within the land mass by several land owners or users. The fourth and eighth land mass (Figure 2 and Figure 3 ) include the striped land plots of private land owners, which form interspersed contours with the total area of 70290 sq. m. and 58998 sq. m. within the land masses rented by the agricultural enterprise. Vehicle access to the land plots is provided by the auxiliary field roads 700 and 410 meters long respectively. The eleventh land mass (Figure 4) is close to the striped one by its spatial placement characteristics, because it is formed of two parts having the common boundary of approximately 37 meters only.

According to the existing conditions, the exchange has typical aims of the agricultural land plots spatial characteristics improvement (Malashevskyi et al., 2018):

- Land tenure configuration improvement;

- Land plots vehicle access improvement;

- Strip farming removal;

- The reduction of distances from land plots to household buildings or other land plots of the same land owner.

Two land plots exchange options are suggested. In the first case, the exchange is carried out in accordance to legal restrictions for the case when land owners and users can be involved irrespective of their will, in particular, 
by decision of a court. The exchange of land plots placed within one land mass aiming at interspersion removal was stipulated. Accordingly, land plots reallocation within the ninth, eighth and eleventh land mass was carried out (Table 1).

Voluntary land owners participation was stipulated by option II. The exchange of fifteen land plots was carried out; possible land reallotment options without restrictions on the placement in the land mass were scrutinized
(Table 2). At the selection of peer land plots, land owners, for whom the exchange was rewarding from the point of view of the configuration and placement optimization of their own land plots (usually, towards other land plots and household buildings of these land owners), participated at the project.

As we can see from Table 1, 2, in both cases requirements on the land plots normative monetary value difference within the range of $10 \%$ were met at the reallotment.

Table 1. Land plots exchange in the land consolidation project (option I)

\begin{tabular}{|c|c|c|c|c|c|c|c|c|c|c|c|c|c|c|}
\hline \multicolumn{7}{|c|}{ Land plots subject to exchange } & \multicolumn{7}{|c|}{ Land plots chosen for exchange } & \multirow{3}{*}{$\begin{array}{l}\Delta, \\
\%\end{array}$} \\
\hline \multirow{2}{*}{ 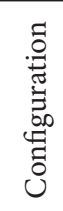 } & \multirow[b]{2}{*}{ 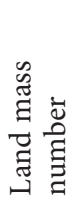 } & \multicolumn{3}{|c|}{ Soil suitability group } & \multirow{2}{*}{ 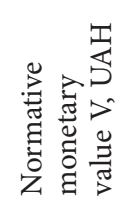 } & \multirow{2}{*}{ 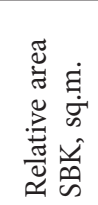 } & \multirow{2}{*}{ 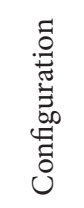 } & \multirow[b]{2}{*}{ 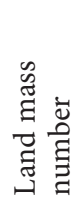 } & \multicolumn{3}{|c|}{ Soil suitability group } & \multirow{2}{*}{ 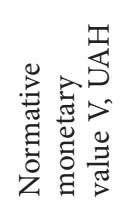 } & \multirow{2}{*}{ 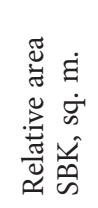 } & \\
\hline & & 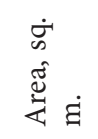 & تँ & 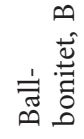 & & & & & 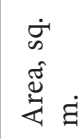 & $\frac{8}{0}$ & 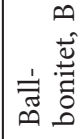 & & & \\
\hline & IV & 23428 & 53Д & 63 & 101740.9 & 129.05 & & IV & 23400 & 53Д & 63 & 101628.0 & 125.28 & +0.1 \\
\hline & IV & 23431 & 53Д & 63 & 101753.9 & 129.12 & & IV & 23400 & 53Д & 63 & 101619.3 & 128.86 & +0.1 \\
\hline & IV & 23431 & 53Д & 63 & 101753.9 & 129.12 & & IV & 23399 & 53Д & 63 & 101614.9 & 129,04 & +0.1 \\
\hline & & & & & & & & & 21445 & 41Д & 50 & & & \\
\hline & VIII & 29500 & $41 д$ & 50 & 101674.4 & 133.34 & & VIII & 9479 & 49Д & 39 & 99394.7 & 131.72 & +2.2 \\
\hline & & & & & & & & & 23092 & 41Д & 50 & & & \\
\hline & VIII & 29498 & 41Д & 50 & 101667.5 & 133.32 & & VIII & 10483 & 49Д & 39 & 107770.7 & 133.85 & -6.0 \\
\hline & & 9187 & $41 Д$ & 50 & & & & & 9914 & 41Д & 50 & & & \\
\hline & XI & 7914 & 53Д & 63 & 106813.8 & 143.71 & & XI & & & & 110974.3 & 146.55 & +3.7 \\
\hline & & 14699 & 49 Д & 39 & & & & & 17686 & 53Д & 63 & & & \\
\hline & & 8310 & 41Д & 50 & & & & & & & & & & \\
\hline & XI & 7170 & 53Д & 63 & 97347.6 & 127.87 & & XI & 30200 & 41Д & 50 & 103990.5 & 139.95 & +6.4 \\
\hline & & 13434 & 49Д & 39 & & & & & & & & & & \\
\hline
\end{tabular}

Note: $\Delta-$ is the difference of the land plots normative monetary values.

Table 2. Land plots exchange in the land consolidation project (option II)

\begin{tabular}{|c|c|c|c|c|c|c|c|c|c|c|c|c|c|c|}
\hline \multicolumn{7}{|c|}{ Land plots subject to exchange } & \multicolumn{7}{|c|}{ Land plots chosen for exchange } & \multirow{3}{*}{$\begin{array}{c}\Delta^{\star} \\
\%\end{array}$} \\
\hline \multirow{2}{*}{ 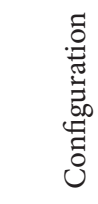 } & \multirow[b]{2}{*}{ 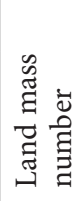 } & \multicolumn{3}{|c|}{ Soil suitability group } & \multirow[b]{2}{*}{ 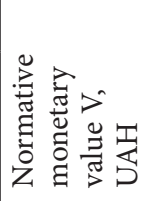 } & \multirow{2}{*}{ 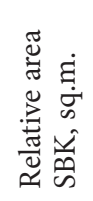 } & \multirow{2}{*}{ 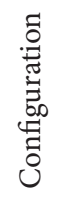 } & \multirow[b]{2}{*}{ 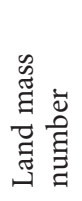 } & \multicolumn{3}{|c|}{ Soil suitability group } & \multirow[b]{2}{*}{ 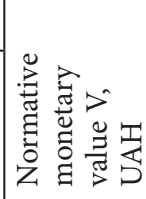 } & \multirow{2}{*}{ 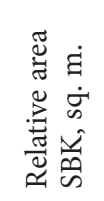 } & \\
\hline & & 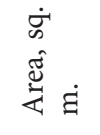 & נ艹 & 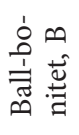 & & & & & 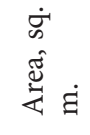 & تัن & ص & & & \\
\hline \multirow[t]{3}{*}{ ans } & \multirow{3}{*}{ XI } & 14130 & 53Д & 63 & \multirow{3}{*}{104999.4} & \multirow{3}{*}{131.47} & & \multirow{3}{*}{ IV } & \multirow{3}{*}{23428} & \multirow{3}{*}{ 53Д } & \multirow{3}{*}{63} & \multirow{3}{*}{101740.9} & \multirow{3}{*}{129.05} & \multirow{3}{*}{-3.2} \\
\hline & & 10048 & 55Д & 53 & & & & & & & & & & \\
\hline & & 2010 & 41Д & 50 & & & & & & & & & & \\
\hline
\end{tabular}


End of Table 2.

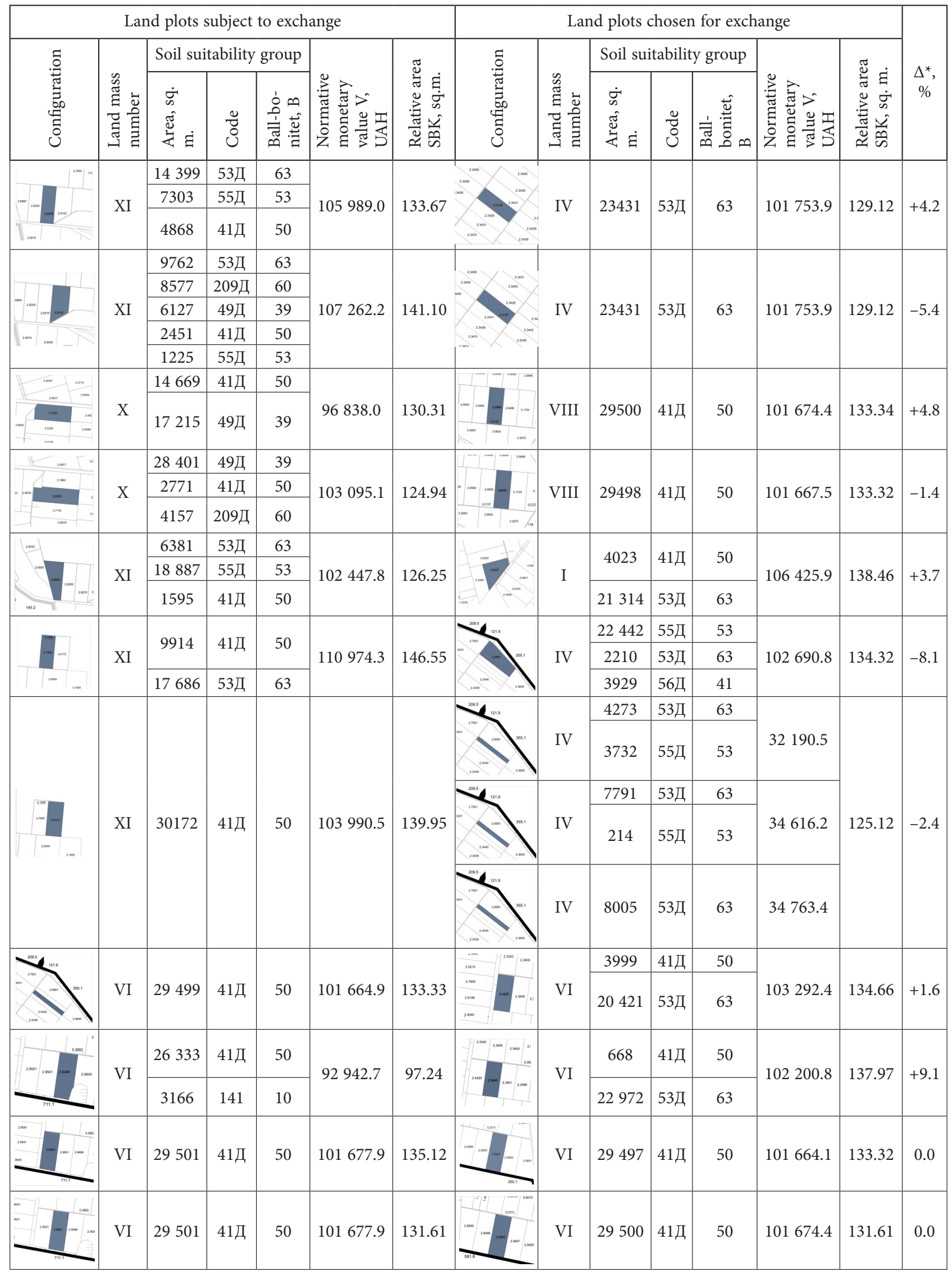

Note: $\Delta-$ is the difference of the land plots normative monetary values. 


\section{Result and discussion}

As the result of exchange by option I, the agricultural enterprise land tenure configuration was improved, the need for additional field roads disappeared (the fourth and eighth land mass) (Figure 10).

However, the potential capacity of the configuration optimization within land masses was not fully realized and exploited due to restrictions on the involvement of land plots at the land mass boundaries and reallotment exclusively within the land mass. Land plots configuration was improved due to the interspersion removal (Table 3).

However, the exchange facilitated the net income increase due to the reduction of handling costs and the reduction of the uncultivated or cultivated with the technological process violation areas (Table 4).

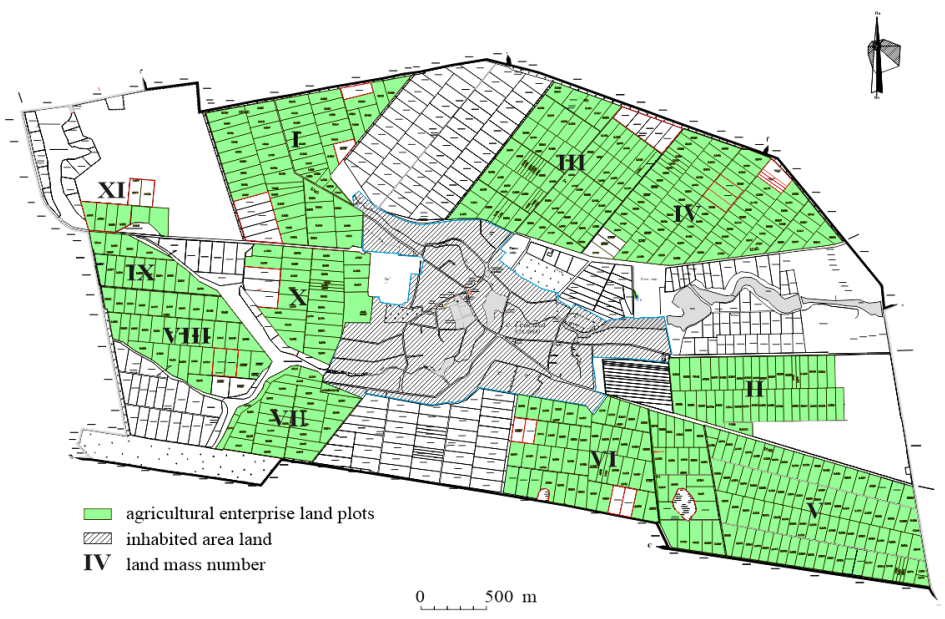

Figure 10. Land consolidation through land plots exchange (option I)

Table 3. Agricultural enterprise land tenure characteristics (option I)

\begin{tabular}{|c|c|c|c|c|c|c|c|c|c|}
\hline \multirow{3}{*}{$\begin{array}{c}\text { Land } \\
\text { mass } \\
\text { number }\end{array}$} & \multirow{3}{*}{$\begin{array}{c}\text { The number } \\
\text { of rented } \\
\text { land plots }\end{array}$} & \multicolumn{4}{|c|}{ Before land consolidation } & \multicolumn{4}{|c|}{ After land consolidation } \\
\hline & & \multirow{2}{*}{$\begin{array}{l}\text { Field area, } \\
\text { ths. sq. m }\end{array}$} & \multicolumn{2}{|c|}{ Soil suitability groups } & \multirow{2}{*}{$\begin{array}{c}\text { Average } \\
\text { furrow } \\
\text { length, m }\end{array}$} & \multirow{2}{*}{$\begin{array}{l}\text { Field area, } \\
\text { ths. sq. m. }\end{array}$} & \multicolumn{2}{|c|}{ Soil suitability groups } & \multirow{2}{*}{$\begin{array}{c}\text { Average } \\
\text { furrow } \\
\text { length, m }\end{array}$} \\
\hline & & & Code & Area, ths. sq. $\mathrm{m}$ & & & Code & Area, ths. sq. $\mathrm{m}$ & \\
\hline \multirow{4}{*}{ I } & \multirow{4}{*}{52} & \multirow{4}{*}{1593} & $41 д$ & 852 & \multirow{4}{*}{840.0} & \multirow{4}{*}{1593} & $41 д$ & 852 & \multirow{4}{*}{842.0} \\
\hline & & & 49д & 676 & & & 49 д & 676 & \\
\hline & & & 53д & 27 & & & 53д & 27 & \\
\hline & & & 209д & 38 & & & 209 д & 38 & \\
\hline \multirow{4}{*}{ II } & \multirow{4}{*}{40} & \multirow{4}{*}{980} & 53д & 620 & \multirow{4}{*}{1450.0} & \multirow{4}{*}{980} & 53д & 620 & \multirow{4}{*}{1450.0} \\
\hline & & & 55 д & 300 & & & $55 д$ & 300 & \\
\hline & & & 56д & 54 & & & $56 д$ & 54 & \\
\hline & & & $210 д$ & 6 & & & $210 д$ & 6 & \\
\hline \multirow{3}{*}{ III } & \multirow{3}{*}{77} & \multirow{3}{*}{1708} & $41 д$ & 280 & \multirow{3}{*}{1439.1} & \multirow{3}{*}{1708} & $41 д$ & 280 & \multirow{3}{*}{1439.1} \\
\hline & & & 53д & 1382 & & & 53д & 1382 & \\
\hline & & & 55д & 46 & & & $55 д$ & 46 & \\
\hline \multirow{3}{*}{ IV } & \multirow{3}{*}{73} & \multirow{3}{*}{1700} & 53д & 1575 & \multirow{3}{*}{1083.5} & & 53д & 1575 & \\
\hline & & & 55д & 110 & & 1700 & 55д & 110 & 1189.4 \\
\hline & & & 209д & 15 & & & 209д & 15 & \\
\hline & & & 41д & 153 & & & 41д & 153 & \\
\hline V & 86 & 2006 & 53д & 1723 & 1535.0 & 2006 & $53 д$ & 1723 & 1535.0 \\
\hline & & & 55д & 130 & & & 55д & 130 & \\
\hline & & & $41 д$ & 1066 & & & $41 д$ & 1066 & \\
\hline & & & 53д & 705 & & & 53д & 705 & \\
\hline VI & 69 & 1853 & 55 д & 67 & 1035.0 & 1853 & $55 д$ & 67 & 1035.0 \\
\hline & & & 209д & 12 & & & 209д & 12 & \\
\hline & & & 141 & 3 & & & 141 & 3 & \\
\hline
\end{tabular}


End of Table 3

\begin{tabular}{|c|c|c|c|c|c|c|c|c|c|}
\hline \multirow{3}{*}{$\begin{array}{l}\text { Land } \\
\text { mass } \\
\text { number }\end{array}$} & \multirow{3}{*}{$\begin{array}{c}\text { The number } \\
\text { of rented } \\
\text { land plots }\end{array}$} & \multicolumn{4}{|c|}{ Before land consolidation } & \multicolumn{4}{|c|}{ After land consolidation } \\
\hline & & \multirow{2}{*}{$\begin{array}{l}\text { Field area, } \\
\text { ths. sq. m }\end{array}$} & \multicolumn{2}{|c|}{ Soil suitability groups } & \multirow{2}{*}{$\begin{array}{l}\text { Average } \\
\text { furrow } \\
\text { length, m }\end{array}$} & \multirow{2}{*}{$\begin{array}{l}\text { Field area, } \\
\text { ths. sq. m. }\end{array}$} & \multicolumn{2}{|c|}{ Soil suitability groups } & \multirow{2}{*}{$\begin{array}{l}\text { Average } \\
\text { furrow } \\
\text { length, } m\end{array}$} \\
\hline & & & Code & Area, ths. sq. m & & & Code & Area, ths. sq. m & \\
\hline \multirow{4}{*}{ VII } & \multirow{4}{*}{26} & \multirow{4}{*}{505} & 53д & 98 & \multirow{4}{*}{1125.0} & \multirow{4}{*}{505} & 53д & 98 & \multirow{4}{*}{1125.0} \\
\hline & & & 55д & 351 & & & 55д & 351 & \\
\hline & & & 56д & 50 & & & 56д & 50 & \\
\hline & & & 210д & 6 & & & 210д & 6 & \\
\hline \multirow{3}{*}{ VIII } & \multirow{3}{*}{33} & \multirow{3}{*}{971} & 41д & 673 & \multirow{3}{*}{930.8} & \multirow{3}{*}{965} & $41 д$ & 687 & \multirow{3}{*}{1150.0} \\
\hline & & & 49д & 131 & & & 49д & 111 & \\
\hline & & & 53д & 167 & & & 53д & 167 & \\
\hline \multirow{4}{*}{ IX } & \multirow{4}{*}{14} & \multirow{4}{*}{382} & 41д & 188 & \multirow{4}{*}{599.6} & \multirow{4}{*}{382} & 41д & 188 & \multirow{4}{*}{599.6} \\
\hline & & & 49д & 3 & & & 49д & 3 & \\
\hline & & & 53д & 185 & & & 53д & 185 & \\
\hline & & & 210д & 6 & & & $210 д$ & 6 & \\
\hline \multirow{4}{*}{$X$} & \multirow{4}{*}{30} & \multirow{4}{*}{858} & 41д & 370 & \multirow{4}{*}{845.0} & & 41д & 370 & \\
\hline & & & 49д & 410 & & 858 & 49д & 410 & 8450 \\
\hline & & & 209д & 63 & & 000 & 209д & 63 & 045.0 \\
\hline & & & $210 д$ & 15 & & & 210д & 15 & \\
\hline & & & 41д & 66 & & & 41д & 43 & \\
\hline & & & 55д & 36 & & & 55д & 36 & \\
\hline XI & 6 & 166 & 53д & 55 & 337.2 & 169 & 53д & 52 & 730.7 \\
\hline & & & $209_{\pi}$ & 0 & & & 209д & 9 & \\
\hline & & & टणन म & (1) & & & 49д & 28 & \\
\hline Total & 506 & 12722 & - & 12722 & - & 12719 & - & 12719 & - \\
\hline
\end{tabular}

Table 4. Agricultural enterprise land consolidation economic effectiveness (option I)

\begin{tabular}{|c|c|c|c|c|c|c|}
\hline Agricultural crop & $\begin{array}{l}\text { Cultivated area, } \\
\text { ths. sq. m }\end{array}$ & $\begin{array}{l}\text { Crop } \\
\text { productivity, } \\
\text { kg/ths. sq. m }\end{array}$ & $\begin{array}{l}\text { Gross output, } \\
\text { ths. kg }\end{array}$ & $\begin{array}{l}\text { Gross income, } \\
\text { ths. UAH }\end{array}$ & $\begin{array}{l}\text { Total expenses, } \\
\text { ths. UAH }\end{array}$ & $\begin{array}{c}\text { Net income, } \\
\text { ths. UAH }\end{array}$ \\
\hline \multicolumn{7}{|c|}{ Actual values } \\
\hline Corn & 1951 & 890.1 & 1736.59 & 7177.84 & 3059.19 & 4118.65 \\
\hline Winter wheat & 5204 & 627.0 & 3262.91 & 16665.61 & 5578.69 & 11086.92 \\
\hline Spring barley & 1853 & 444.6 & 823.84 & 4100.35 & 3059.28 & 1041.07 \\
\hline Sunflower & 2006 & 297.0 & 595.78 & 5287.58 & 1625.79 & 3661.79 \\
\hline Soya & 1708 & 205.4 & 350.82 & 3121.76 & 1609.60 & 1512.16 \\
\hline Total & 12722 & - & 6769.94 & 36353.14 & 14932.55 & 21420.59 \\
\hline \multicolumn{7}{|c|}{ Design target values } \\
\hline Corn & 1945 & 890.1 & 1731.29 & 7155.95 & 2006.74 & 5149.21 \\
\hline Winter wheat & 5207 & 627.0 & 3264.53 & 16673.91 & 3665.87 & 13008.04 \\
\hline Spring barley & 1853 & 444.6 & 823.78 & 4100.05 & 3059.28 & 1040.77 \\
\hline Sunflower & 2006 & 297.0 & 595.78 & 5287.57 & 1625.79 & 3661.78 \\
\hline Soya & 1708 & 205.4 & 350.82 & 3121.77 & 1052.77 & 2069.00 \\
\hline Total & 12719 & - & 6766.20 & 36339.25 & 11410.45 & 24928.80 \\
\hline
\end{tabular}


At the exchange by the option II, as compared with the option I, the number of reallotment options is increased due to a wider choise of land plots to be exchanged (Figure 11).

By exchange within the boundaries of the fourth and eighth land mass, not only are interspersions and the need for auxiliary field roads removed. Also, all land plots of the respective land masses became the land tenure of an agricultural enterprise (Figure 11, Table 5). The eleventh land mass which had inconvenient configuration and placement (Figure 4), is withdrawn from the agricultural enterprise land tenure after the exchange; configuration of the tenth, first and sixth land mass is improved.

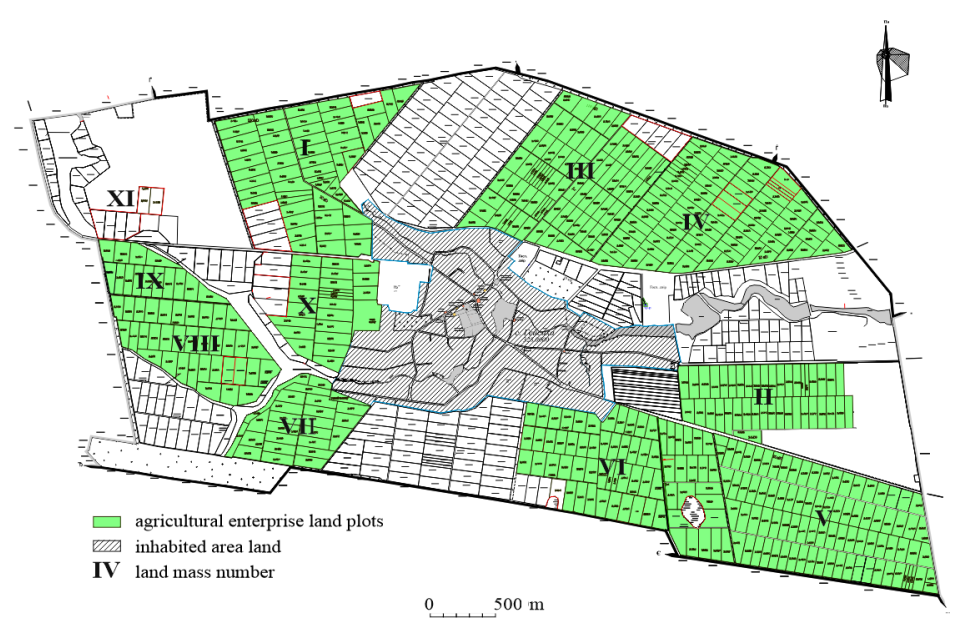

Figure 11. Land consolidation through land plots exchange (option II)

Table 5. Agricultural enterprise land tenure characteristics (option II)

\begin{tabular}{|c|c|c|c|c|c|c|c|c|c|c|}
\hline \multirow{3}{*}{$\begin{array}{c}\text { Land } \\
\text { mass } \\
\text { number }\end{array}$} & \multicolumn{5}{|c|}{ Before land consolidation } & \multicolumn{5}{|c|}{ After land consolidation } \\
\hline & \multirow{2}{*}{$\begin{array}{l}\text { Rented } \\
\text { land plots } \\
\text { number }\end{array}$} & \multirow{2}{*}{$\begin{array}{c}\text { Field } \\
\text { area, } \\
\text { ths. sq. m }\end{array}$} & \multicolumn{2}{|c|}{ Soil suitability groups } & \multirow{2}{*}{$\begin{array}{l}\text { Average } \\
\text { furrow } \\
\text { length, m }\end{array}$} & \multirow{2}{*}{$\begin{array}{l}\text { Rented } \\
\text { land plots } \\
\text { number }\end{array}$} & \multirow{2}{*}{$\begin{array}{l}\text { Field } \\
\text { area, } \\
\text { ths. sq. } \\
\text { m }\end{array}$} & \multicolumn{2}{|c|}{ Soil suitability groups } & \multirow{2}{*}{$\begin{array}{l}\text { Average } \\
\text { furrow } \\
\text { length, m }\end{array}$} \\
\hline & & & Code & $\begin{array}{l}\text { Area, } \\
\text { ths. sq. m }\end{array}$ & & & & Code & $\begin{array}{l}\text { Area, } \\
\text { ths. sq. m }\end{array}$ & \\
\hline \multirow{4}{*}{ I } & \multirow{4}{*}{52} & \multirow{4}{*}{1593} & $41 д$ & 852 & \multirow{4}{*}{840.0} & \multirow{4}{*}{53} & \multirow{4}{*}{1618} & 41д & 856 & \multirow{4}{*}{842.0} \\
\hline & & & 49 д & 676 & & & & 49 д & 676 & \\
\hline & & & 53д & 27 & & & & 53д & 48 & \\
\hline & & & 209д & 38 & & & & 209 д & 38 & \\
\hline \multirow{4}{*}{ II } & \multirow{4}{*}{40} & \multirow{4}{*}{980} & 53д & 620 & \multirow{4}{*}{1450.0} & \multirow{4}{*}{40} & \multirow{4}{*}{980} & 53д & 620 & \multirow{4}{*}{1450.0} \\
\hline & & & $55 д$ & 300 & & & & $55 д$ & 300 & \\
\hline & & & $56 д$ & 54 & & & & 56д & 54 & \\
\hline & & & 210д & 6 & & & & 210 д & 6 & \\
\hline \multirow{3}{*}{ III } & \multirow{3}{*}{77} & \multirow{3}{*}{1708} & $41 д$ & 280 & \multirow{3}{*}{1439.1} & \multirow{3}{*}{77} & \multirow{3}{*}{1708} & $41 д$ & 280 & \\
\hline & & & 53д & 1382 & & & & 53д & 1382 & 1439.1 \\
\hline & & & $55 д$ & 46 & & & & $55 д$ & 46 & \\
\hline & & & 53д & 1575 & & & & 53д & 1669 & \\
\hline IV & 73 & 1700 & 55д & 110 & 10825 & 80 & 1826 & $55 д$ & 138 & ת \\
\hline IV & 13 & 1700 & $200_{\pi}$ & 15 & 1083.5 & 80 & 1020 & 209д & 15 & 1410.0 \\
\hline & & & & & & & & 56д & 4 & \\
\hline & & & 41д & 153 & & & & 41д & 153 & \\
\hline V & 86 & 2006 & $53 д$ & 1723 & 1535.0 & 86 & 2006 & $53 д$ & 1723 & 1535.0 \\
\hline & & & 55д & 130 & & & & $55 д$ & 130 & \\
\hline & & & $41 д$ & 1066 & & & & $41 д$ & 1015 & \\
\hline & & & 53д & 705 & & & & 53д & 748 & \\
\hline VI & 69 & 1853 & $55 д$ & 67 & 1035 & 69 & 1842 & $55 д$ & 67 & 1062.0 \\
\hline & & & 209д & 12 & & & & & & \\
\hline & & & 141 & 3 & & & & 209д & 12 & \\
\hline
\end{tabular}


End of Table 5

\begin{tabular}{|c|c|c|c|c|c|c|c|c|c|c|}
\hline \multirow{3}{*}{$\begin{array}{c}\text { Land } \\
\text { mass } \\
\text { number }\end{array}$} & \multicolumn{5}{|c|}{ Before land consolidation } & \multicolumn{5}{|c|}{ After land consolidation } \\
\hline & \multirow{2}{*}{$\begin{array}{l}\text { Rented } \\
\text { land plots } \\
\text { number }\end{array}$} & \multirow{2}{*}{$\begin{array}{c}\text { Field } \\
\text { area, } \\
\text { ths. sq. m }\end{array}$} & \multicolumn{2}{|c|}{ Soil suitability groups } & \multirow{2}{*}{$\begin{array}{c}\text { Average } \\
\text { furrow } \\
\text { length, m }\end{array}$} & \multirow{2}{*}{$\begin{array}{l}\text { Rented } \\
\text { land plots } \\
\text { number }\end{array}$} & \multirow{2}{*}{$\begin{array}{l}\text { Field } \\
\text { area, } \\
\text { ths. sq. } \\
\text { m }\end{array}$} & \multicolumn{2}{|c|}{ Soil suitability groups } & \multirow{2}{*}{$\begin{array}{l}\text { Average } \\
\text { furrow } \\
\text { length, m }\end{array}$} \\
\hline & & & Code & $\begin{array}{l}\text { Area, } \\
\text { ths. sq. m }\end{array}$ & & & & Code & $\begin{array}{l}\text { Area, } \\
\text { ths. sq. m }\end{array}$ & \\
\hline \multirow{4}{*}{ VII } & \multirow{4}{*}{26} & \multirow{4}{*}{505} & 53д & 98 & \multirow{4}{*}{1125.0} & \multirow{4}{*}{26} & \multirow{4}{*}{505} & $53 д$ & 98 & \multirow{4}{*}{1210.0} \\
\hline & & & $55 д$ & 351 & & & & $55 д$ & 351 & \\
\hline & & & 56д & 50 & & & & 56д & 50 & \\
\hline & & & 210д & 6 & & & & 210д & 6 & \\
\hline \multirow{3}{*}{ VIII } & \multirow{3}{*}{33} & \multirow{3}{*}{971} & $41 д$ & 673 & \multirow{3}{*}{930.8} & \multirow{3}{*}{35} & \multirow{3}{*}{1032} & $41 д$ & 734 & \multirow{3}{*}{1150.0} \\
\hline & & & $49 д$ & 131 & & & & 49д & 131 & \\
\hline & & & 53д & 167 & & & & 53д & 167 & \\
\hline \multirow{4}{*}{ IX } & \multirow{4}{*}{14} & \multirow{4}{*}{382} & $41 д$ & 188 & \multirow{4}{*}{599.6} & \multirow{4}{*}{14} & \multirow{4}{*}{382} & $41 д$ & 188 & \multirow{4}{*}{599.6} \\
\hline & & & 49 д & 3 & & & & 49 д & 3 & \\
\hline & & & 53д & 185 & & & & $53 д$ & 185 & \\
\hline & & & 210д & 6 & & & & 210д & 6 & \\
\hline & & & 41д & 370 & & & & 41д & 353 & \\
\hline $\mathrm{x}$ & & 850 & $49 д$ & 410 & & & & 49д & 364 & \\
\hline$X$ & 30 & 858 & 209д & 63 & 845.0 & 28 & 791 & 209д & 59 & 846.0 \\
\hline & & & 210д & 15 & & & & 210д & 15 & \\
\hline & & & 41д & 66 & & & & & & \\
\hline & & & 55д & 36 & & & & & & \\
\hline $\mathrm{XI}$ & 6 & 166 & 53д & 55 & 337.2 & 0 & 0 & - & - & - \\
\hline & & & 209д & 9 & & & & & & \\
\hline Total & 506 & 12722 & - & 12722 & - & 508 & 12691 & & 12691 & \\
\hline
\end{tabular}

Thus, as the result of the respective measures, the land tenure has acquired a compact form, the number of land masses in the land tenure has been reduced, their areas have been increased, their configuration has been improved (Table 6). As the result of land exchange by the option II, agricultural enterprise net operating income has been increased by $3997750.25 \mathrm{UAH}$.

Exchange by the option II is more cost efficient. In both cases, the economic activity environment did not deteriorate for any of land owners and land users involved in

Table 6. Agricultural enterprise land consolidation economic effectiveness (option II)

\begin{tabular}{|l|c|c|c|c|c|c|}
\hline \multicolumn{1}{|c|}{ Agricultural crop } & $\begin{array}{c}\text { Cultivated area, } \\
\text { ths. sq. } \mathrm{m}\end{array}$ & $\begin{array}{c}\text { Crop productivity, } \\
\text { kg/ths. sq. } \mathrm{m}\end{array}$ & $\begin{array}{c}\text { Gross output, } \\
\text { ths. kg }\end{array}$ & $\begin{array}{c}\text { Gross income, } \\
\text { ths. UAH }\end{array}$ & $\begin{array}{c}\text { Total expenses, } \\
\text { ths. UAH }\end{array}$ & $\begin{array}{c}\text { Net income, } \\
\text { ths. UAH }\end{array}$ \\
\hline \multicolumn{7}{|c|}{ Actual values } \\
\hline Corn & 1951 & 890.1 & 1736.59 & 7177.84 & 3059.19 & 4118.65 \\
\hline Winter wheat & 5204 & 627.0 & 3262.91 & 16665.61 & 5578.69 & 11086.92 \\
\hline Spring barley & 1853 & 444.6 & 823.84 & 4100.35 & 3059.28 & 1041.07 \\
\hline Sunflower & 2006 & 297.0 & 595.78 & 5287.58 & 1625.79 & 3661.79 \\
\hline Soya & 1708 & 205.4 & 350.82 & 3121.76 & 1609.60 & 1512.16 \\
\hline Total & 12722 & - & 6769.94 & 36353.14 & 14932.55 & 21420.59 \\
\hline \multicolumn{7}{|c|}{ Design target values } \\
\hline Corn & 2012 & 890.1 & 1790.97 & 7402.63 & 2070.99 & 5331.64 \\
\hline Winter wheat & 5123 & 627.0 & 3211.56 & 16403.35 & 2070.99 & 14332.36 \\
\hline Spring barley & 1842 & 444.6 & 818.92 & 4075.83 & 3034.06 & 1041.77 \\
\hline Sunflower & 2006 & 297.0 & 595.78 & 5287.57 & 1625.79 & 3661.78 \\
\hline Soya & 1708 & 205.4 & 350.82 & 3121.77 & 2070.99 & 1050.78 \\
\hline Total & 12691 & - & 6768.05 & 36291.15 & 10872.81 & 25418.34 \\
\hline
\end{tabular}


the project after the reallotment implementation. Agricultural enterprise rented land area alteration resulted from land plots exchange and the lease of field roads used to access the striped land plots by the agricultural enterprise (such lease is prescribed by the legislation in effect).

The exchange calculation by the relative value using optimization models provides the necessary substantiation. The results of the research witness in favour of option II, which preconditioned voluntary land owners and users participation and excludes additional costs and the reallotment delay due to the exchange appeal.

\section{Conclusions}

According to the research, the effectiveness of land plots exchange aiming at the configuration improvement, the reduction of the number of the striped land plots in the land tenure and the reduction of distances between the striped land plots has been substantiated. The complete substantiation is important for both comprehensive and voluntary land consolidation. The suggested methodology allows to choose the optimal land reallotment option and guarantee the absence of losses for a land owner involved in the project without the alteration of the legislation in effect.

The effectiveness of land exchange by the relative value defined by the collective estimate of the land plot soil quality, area, relief and configuration has been substantiated. The existing modeling approaches have been supplemented with the demands on the exchanged land plots relative value acceptable difference due to the existing land plots boundaries retaining at the exchange. For big land users, the demands on the formation of the most possible compact land tenure with the longest possible furrow and the avoiding of boundaries folding, cutting-in and excessive triangles have been defined. For small land users, demands on the placement of land plots which are situated on the project territory towards other land plots owned or used by the person have been specified.

The suggested reallotment options witness, the projects developed according to the restrictions on the land plots exchange and predefine the possibility of the compulsory land owners involvement have a relatively low effectiveness in terms of land tenure optimization of both big and small land owners. It is more effective to interest individual land owners to voluntarily participate in the project by the selection of the exchange options taking into consideration the spatial, technological and qualitative land plots characteristics.

It has been observed, in case of land exchange the resolving of reallotment issues in favour of individual small land owners (land users) is justified for big land users. It has been demonstrated with an example that irrespective of the fact the total rented area of a big land user (an agricultural enterprise) was decreased as the result of the exchange, the ultimate economic activities effectiveness was increased due to the reduction of expenses for transportation, cultivation costs and field roads lease which were previously used to approach the interspersed land plots of small land users (households).

\section{References}

Bavarian Ministry of Agriculture and Forestry. (2006). Rural development in Bavaria. http://www.waldbesitzerportal.bayern. $\mathrm{de} / \mathrm{mam} / \mathrm{cms} 01 /$ landentwicklung/dokumentationen/dateien/ le_in_bayern_englisch.pdf

Bugaienko, O. (2019). The land reallocation model in the course of agricultural land consolidation in Ukraine. Geodesy and Cartography, 44(3), 106-112. https://doi.org/10.3846/gac.2018.2049

Cabinet of Ministers of Ukraine. (2006). Methodology of normative monetary valuation of agricultural lands. Uriadovyi $\mathrm{Ku}-$ rier Ukrainian Government Publishing Body.

Food and Agriculture Organization of the United Nations. (2003). The design of land consolidation pilot projects in Central and Eastern Europe (FAO Land Tenure Studies No. 6). Rome. http://www.fao.org/docrep/006/Y4954E/y4954e00.htm

Food and Agriculture Organization of the United Nations. (2012). Voluntary guidelines on the responsible governance of tenure of land, fisheries and forests in the context of national food security. http://www.fao.org/nr/tenure/voluntary-guidelines/en/

Food and Agriculture Organization of the United Nations. (2017). FAO advises on land consolidation legislation in Ukraine. http://www.fao.org/europe/news/detail-news/ en/c/1068717/

Gedefaw, A. A., Atzberger, C., Seher, W., \& Mansberger, R. (2019). Farmers willingness to participate in voluntary land consolidation in Gozamin District, Ethiopia. Land, 8, 148. https://doi.org/10.3390/land8100148

Giovarelli, R., \& Bledsoe, D. (2001). Land reform in Eastern Europe - Western CIS, Transcaucuses, Balkans, and EU accession countries. Seattle, Washington.

Hartvigsen, M. (2014). Land reform and land fragmentation in Central and Eastern Europe. Land Use Policy, 36, 330-341. https://doi.org/10.1016/j.landusepol.2013.08.016

Hartvigsen, M. (2016). Land consolidation in Central and Eastern Europe - integration with local rural development needs. In 2016 World Bank Conference on Land and Poverty. Washington, USA.

Kik, R. (1980). Reallotment of farm lands by computer (pp. 179181). Research digest. Louwsma, M., Van Beek, M., \& Hoeve, B. (2014). A new approach: Participatory land consolidation. In FIG Congress 2014 Engaging the Challenges - Enhancing the Relevance, Kuala Lumpur, Malaysia.

Malashevskyi, M., Palamar, A., Malanchuk, M., Bugaienko, O., \& Tarnopolsky, E. (2018). The opportunities for use the peer land exchange during land management in Ukraine. Geodesy and Cartography, 42(4), 129-133. https://doi.org/10.3846/gac.2018.5405

Mihajlovic, R., Miladinovic, M., \& Šoškic, M. (2011). Optimization of land distribution in land consolidation. Geodetski list, 2, 109-121.

Sonnenberg, J. (2002). Fundamentals of land consolidation as an instrument to abolish fragmentation of agricultural holdings. In FIG XXII International Congress, Washington, D.C. USA.

Sulonena, K., Kotilainen, S., \& Hiironen, J. (2017). Voluntary land consolidation approaches and their adaptability to ex- 
perimental farm-based land consolidation in Finland. Nordic Journal of Surveying and Real Estate Research, 12(1), 59-83.

Thomas, J. (2006). Attempt on systematization of land consolidation approaches in Europe. Fachbeitrag, 3, 156-161.

Verkhovna Rada of Ukraine. (1998). On land lease. Uriadovyi Kurier Ukrainian Government Publishing Body.

Verkhovna Rada of Ukraine. (2001). The land code of Ukraine. Uriadovyi Kurier Ukrainian Government Publishing Body.

Vitikainen, A. (2004). An overview of land consolidation in Europe. Nordic Journal of Surveying and Real Estate Research, 1(1), 25-44.

Yimer, F. A. (2014). Fit-for-purpose land consolidation: An innovative tool for re-allotment in Rural Ethiopia [MSc Thesis]. University of Twente Faculty of Geo-Information and Earth Observation, Enschede, The Netherlands. 